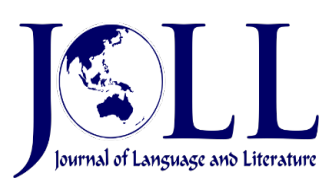

Vol. 21 No. 1, April 2021, pp. 48 - 57

DOI: 10.24071/joll.v21i1.2687

Available at https://e-journal.usd.ac.id/index.php/JOLL/index

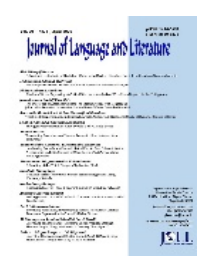

This work is licensed under a Creative Commons Attribution-ShareAlike 4.0 International License.

\title{
Posthumanism in Hernan Diaz's In the Distance
}

\author{
Pegah Abedi \& Rasool Moradi-Joz \\ pegahi.abd@gmail.com \&moradijoz@znu.ac.ir \\ Department of English Language and Literature, University of Zanjan, IRAN
}

\begin{abstract}
This study is an attempt to shed new light on the potential representation of posthumanism, the posthuman condition in particular, in Hernan Diaz's tour de force novel entitled "In the Distance." The main focus of the study is highlighting the inextricable bond between humans and their surroundings in the most anthropocentric trend of posthumanism, and addressing our exploitative way of living and the outcomes of our ill-treatment toward the natural environment, as represented in one of the contemporary fictions, "In the Distance." We are told that nature is an eternal Eden which was predestined for serving humankind, and will be balanced once it has fulfilled its duty. The novel, however, as evidenced by current environmental issues, makes an effort to warn us about the end of nature and in turn the failure of humanity. In the same context, this study seeks to demonstrate the "In the Distance" novel as one of the main works arguing for post-humanistic principles during and after the colonialization of America, accompanied by modern civilization and technological advancement in the late 19th and early 20th century.
\end{abstract}

Article

information

Received:

29 June

2020

Revised:

19 October

2020

Accepted:

11 December

2020

Keywords: posthumanism; anthropocentrism; environment; modernism

\section{Introduction}

There have been many efforts by philosophers and critical theorists to question, shift, and even remove the boundaries among all living beings, especially those that man has installed between human and non-human matters, including animals and nature. As Badmington (2003) maintains in his earlier "Theorizing Posthumanism", posthumanism reflects the probability that earlier phenomena (Like improvements in technology or findings of animals) are directing to the underlying transition in humanity. The earlier humanist representations which can be located in seventeenth-century writings, particularly in Descartes's, indicate that the human has a legitimate and immortal place at the heart of everything, where it is identified from environment and animals (Badmington, 2003).

Posthumanism resists the old claim on the uniqueness of man and as Serenella Iovino (2016) states, "If there is a basic premise of posthuman thinking, it is that the idea of the 
human is not Platonic in itself, but it is always ready plotted." In this regard, posthumanism rethinks the nature of humanity and its connection with the planet and focuses the deep-seated interrelations among various forms of life as well as the liability of social practices to the environment (Iovino, 2016). Therefore, it includes fundamentally reexamining the prevailing, typical humanist story of who "we" are as individuals and how we are persistently objectifying the existing realm of nature instead of respecting it. The moral assumptions of humans' abusing habits for both the human and the natural world are mostly argued in ecocriticism and portrayed as a theory of the environmental studies in literature. Literature then manages to remind us of the catastrophes of our mistreatments toward nature and animals in the concept of "Posthumanism" by illustrating the soon annihilation of humans as a result of his practices (Gerhardt, 2006).

The emergence of posthumanism is widely renowned for Donna Haraway, who has depicted cyborg creature as a natural/artificial hybrid in A Cyborg Manifesto in 1985. However, Marry Shelly's Frankenstein (1823) might be one of the earliest sources of Ecological posthuman reflection about the status and abilities of humans in the universe. In perusing Frankenstein novel, we can run into the fall down of a primary oppositional binary between non-human and human since Shelly vividly illustrates Victor Frankenstein's failure to enslave nature for his egomaniacal intentions, "Thus, the conception of the human can no longer hinge on a binary opposition to the non-human animal" (Rastelli, 2019; Walter, 2019). Right through the Frankenstein novel, the monster stands for a part of the unnatural environment, something constructed based on modern knowledge and "the nature that (did not) give it birth" (LeMenager, Shewry, \& Hiltner, 2011). Humans took aim at the natural world by misusing modern technology, which paved the way for generating an immortal monster. To Shelly, this is where humanity is rearranging all his constraints and seeks the power that does not belong to him.

The current Canadian author, Margaret Atwood, is a well-known novelist for her post- humanist world view in many of her novels. We can observe the shade of the posthumanist approach from the beginning in her first published fiction, the edible woman (1969), which demonstrates Marian's fiancé as a self-sufficient man who objectifies his surrounding ambiance. The man exploits animals and is entirely apathetic about the moral value of any life form. In fact, gun and knife, which are two handmade tools for hunting and "act as means of annihilation of Peter, therethrough reminding us of the discourse involving posthuman existence." In reading the book, it could be noticed that humans are not unaffected by their illtreatment toward other kinds with whom we share our planet (Oppermann, 2016). In exploring Atwood's next novel, Surfacing (1972), we find out that the anonymous protagonist reappears in her hometown and recalls past events and eventually dives into her childhood and polls out of human society to live in the wild nature. At this point, Skinner (as in (Bandyopadhyay, 2011) comments that by returning to her homeland, the female protagonist reaches the self-knowledge and regain human-nature coexisting consciousness to prove how modern man spoiled the natural environment and himself.

In the same vein, focusing on Cormac McCarthy's (1985) fiction, Blood Meridian's "The Evening Redness in the West," which according to Goodreads website is one of the best English language novels published since the 20th century, highlights the everlasting and indisputable occurrence of natural destruction in a uniquely posthuman approach. In Blood Meridian, the human lives as no more in a prominent position than any other non-human being; therefore, it must struggle with all creatures to state itself as an individual amongst the plenitude. The decentralizing of humankind is a significant theme in McCarthy's fiction and is supported by Cormac's other novels as well. However, "decentralizing" might not be a proper word since "the human has never been at the center of the natural story" (Zimpfer, 2019).

Contextualizing the other work of the Canadian Atwood, The Oryx and Crake (2003), presents us with a moment at which human begin interferes in the natural environment 
and virtue to overcome depravity. In the posthuman atmosphere, it is the preceding mankind attempting to lengthen its presence through devices that has ominous consequences. The story is set for the extinction of humans and other bio-forms as the errancy of mankind to stretch and objectify the environment, leading to a dystopian future (Gonçalves, 2017). From the same perspective, two contradicting lifestyles in a companion novel to The Oryx and Crake can be seen as well. The hypothetical novel, The Year of the Flood (2009), sketches out a society in which a denaturant droughty deluge (which has roots in genetic modification), causes a disastrous influence on both human and non-human presence on earth as "the process had only succeeded in bringing about the destruction of all" (Bandyopadhyay, 2011).

In a groundbreaking article entitled "Back to the Garden: New Visions of Posthuman Futures," Jendrysik (2011) explores the possibility of human extinction in a not so far future, through the lens of environmentalism. He calls for thinking about climate change as the features of nature in the hands of humankind shifted by dystopian technology instructions. At the same time, the author brings up the value of our utopian planet and our dependence on the non-human sphere; mankind, not unlike any other species, he contends, is a part of the original natural world, and his new practices are killing the wild and uninhibited environment. Jendrysik (2011) then explains how, in the best case, our activities bring about the extinction of the human race while nature might survive since "We are, in effect, at war with nature and have been as long as we have had the intelligence to dominate the animals and flora of the planet." Therefore, we ought to rethink the disastrous outcomes of this modern warfare to prevent human vanishing nightmare before it comes real (Jendrysik, 2011).

By considering the shade of posthumanism on each of these works we come across the fact that for many people, different envisions of apocalypse are rooted in wild and untamed nature, although it should be realized that the posture of nature toward man is generally well-disposed and communications among current human and natural milieu is deep-rooted and human dynamism has probably had the most critical impact on the environment thus far. However, humans usually choose to vanquish nature in a high-handed manner and stand as opposed to the natural environment and animals due to long-lasting anthropocentrism (Wang, 2019). Mankind threatens the natural world by means of modern technology, assuming themselves as integral to the natural environment, shifting all their limitations, and continuously seeking domination. It seems that humankind subconsciously is to resist the accountability of his practices on nature and animals and his race as well.

A number of contemporary theorists such as Hayles (2010) focus on conceptualizing posthumanism. However, unlike the Techno and Cyborg posthumanism, little has been said about the underlying notion of the European posthumanism approach, the humannonhuman relationship, and the state of current humans in the natural environment. Rethinking the posthuman as what being human means and how modern practices of human have harmful effects on other species as well as himself can give way to reflecting on one of the contemporary novels to define the human-nonhuman bond and how the latter was exploited by the former since American colonialism till now. This study is thus an attempt to examine In the Distance novel by Hernan Diaz (2017) to announce the unseen posthuman assumption, and oppression of nature and less advanced people throughout America back to the nineteenth century. Through this lens, different scenes of objectifying non-human matters such as animal, mineral, and vegetal forms by modern mankind are portrayed, and the perspectives toward the earth during America's union in nineteenth-century that probably incorporated into loss, melancholy, disappointment, and death of moral values in human society are examined.

Viewed hence, drawing on Hernan Diaz's In the Distance, the present study attempts to illustrate posthumanism as the destiny of humankind since its casts doubt on the mastery of man over non-human, and erodes any track of objectification in the humannonhuman connection. It then insists that we 
must start caring for other beings and refuses the division of animal and human (Westling, 2006). From this perspective, posthumanism eludes discriminating betwixt man and environment, and man is no more acknowledged as a superpower of the universe as he has decentered to an equivalent level to animals and other life forms on the planet (Wang, 2019). In this light, lay waste to nature and act like ecology is a "thing" to consume is thoroughly non-environmental and ends in the disappearance of non-human and humankind. Therefore, by doing so, humankind's anticipatory destiny appears to be sinister and nothing would shield him against his unecological industries (Aretoulakis, 2014).

\section{Posthumanism in Origin}

The term "posthumanism" is generally applied to many current hypothetical notions concerning modern western cultural settlements. However, this theory, notably in literary and cultural studies, originates from Ihab Hassan (1997), the postmodern theorizer who had introduced the definition of posthumanism in his seminal monograph titled "Prometheus as Performer: Towards a Posthumanist Culture?" His article is a resistance to problematical subjective opinions within humanistic and enlightenment schools. It offers a concept for removing or displacing the borders of all living beings on the planet, which facilitates analyzing the human position within the natural ecology of the earth. In other words, posthumanism is constant with outlooks in animal ethics that aims to shrink the concept and value of claims that species borders should have any effect on our moral dedication to various life forms (Hassan, 1977). In this fashion, the broad comprehension of the posthumanism theory also provides us with how up-to-date discussions of posthumanism could encapsulate a reflective standpoint on humanity's discretion and exceptional position in the environment. In this sense, a fundamental assumption of posthumanism is its crucial posture toward the markedness that is afforded to humanity in the original order. Therefore, the "post" of posthumanism does not signify the nonattendance of humanity or moving ahead it; rather, it reminds us of what has been eliminated from an anthropocentric worldview, which entails coming to terms with how the emphasizing humanity has been acknowledged as ineffectual (Bolter, 2016). Only then will our interactions with other creatures be recognized as an aid to realizing powerful forces outside our control (Ağın, 2016).

To move toward the modern era principles, the machine became a gadget of human attention, a means to an end, stressing the position of the human being as a device user. Technological devices were used to strengthen the man's authority and autonomy and, therefore, caused a breakdown in the human-environment relationship, just like a human-made coat separating humans from other creatures (Miah, 2008). The division of man and his surroundings is drawn on principles that seem to be consistent with the post-humanist stance. This argument illustrates the disuse of technology and modern tools in order to dominate nature and exploit it rather than to tackle the environmental issues. Posthumanists do not doubt technology as a cause for the promotion of the human. However, they scrutinize the conditions of an ideal world without humans; therefore, they have been always critical of technological advancement as a particular sort of ill-disposed stance that has destroyed human and non-human interrelation shifted the feature of the world thus far.

The posthuman discourse have also paved the way for establishing a meaningful bond between postcolonialism and the planet ecology. In this regard, posthumanism had given rise to postcolonial studies as a probable connection between ecocriticism and racism and as one of the influential classifications of the environmental analysis, especially in America. However, in the midst of exploration into the nature statues of America, the role of Native Americans is considerable since they stand for nature and are people formerly colonized by the west (Childs \& Williams, 2014). Indigenous Americans are appreciable instances of harmonious human relationships with nature before civilization and misusing modern instruments as a means for dominating the landscape and its creatures (Huggan, 2004). Of course, not only native Indians but also the whole landscape, 
including trees, rivers, birds, fishes, animals, sky, dust, and air, were under the domination of colonizers. These practices began from the 16th century by the kingdom of England and were followed by migration of people from other countries to North America in order to establish colonies until the last waves in the 19th century.

\section{Posthumanism in Practice}

Viewed from the perspective of Kuhn's (1970) scientific revolutions and paradigm theory, posthumanistic studies mainly fall under action-oriented philosophical paradigm, technically labeled as participatory-advocacy paradigm with activist, transformatory, and emancipatory goals. However, posthumanism seems to move beyond uncovering the unequal power relations among human beings, societies, and cultures in part exerted and maintained through ideological moves represented in social actions in a way that it strives to demystify the illusion of human superiority over non-human, which has led to the destruction of environment, thus calling for and incorporating into protection and preservation of the environment.

The study has a textual analysis design with qualitative approach, falling into not only advocacy-liberatory paradigm but also weak version of social constructivism, interpretivism. In this study, the subject under scrutiny is a contemporary novel in which the posthumanism mindset can be observed. In order to affirm a claim as such, the theoretical framework is sketched out drawing on driving forces in posthuman theory and the novel is critiqued within the same conceptual framework.

In the light of posthuman theories, a general and close reading of the work in question, In the distance, would hopefully unveil the probable mentality of the novel's author. Indeed, posthuman theories could reveal whether the hypothesized posthumanistic mentality of Diaz is systematically represented and traceable in his novel or not.

\section{In the Distance and Posthumanism}

The philosophical novel In the Distance by Hernan Diaz describes the journey of a Swedish boy across continents in the 19th century. At this fiction, Diaz is after placing a world wherein both the environment and human existence front a severe hazard due to constant attempts of humankind for ruling over his surroundings. In other words, the anthropocentrism view indicates a lack of consciousness about the possible perils that are anticipating man and nature since human exercises and decisions might determine to be self-destructive in the long-term future.

Diaz's fiction In the Distance initiates in the flat white wasteland, where a hole has interrupted the sea ice, "The hole, a broken star on the ice, was the only interruption on the white plain merging into the white sky. No wind, no life, no sound." (Diaz, 2017) The story starts in an uncharted island, which is wellknown as Alaska, with emptiness, an omission of something that once existed. The cracked ice was extracted from the sea by a man carrying a pickax and rifle, a white man who disturbed the silence of frozen land. This is an interruption of the vast landscape, admittedly, but also a beginning of interference in the whole natural environment by humans. The narrative pauses here (since Diaz decided to apply various genres such as saga, historical fiction, psychological fiction, western fiction, and natural tale on his work), and the novel goes through a flashback to an enigmatic tale of a despondent man.

The story begins in Sweden, where two brothers want to escape the poverty of their homeland and start a journey for a new life in the so-called world of opportunities, America. However, they separated shortly after starting the travel in Portsmouth. Although they had shared their money, they were not prepared for the following situation. Hakan, the younger brother, had to head his way to New York as it was the only place that he and his brother Linus, were capable of spelling. "There was no doubt in his mind that his brother had made it to New York-Linus was much too smart to get lost" so that he left with a ship to find his way to the newly founded continent and revisit his missing brother. Later on, an Irish immigrant family clarifies their destination for Hakan through a map, "That was the first time he 
heard the word California." As he could not speak any English, he thrusts into Bernans and accepts to follow them to San Francisco via Buenos Aires so that he can get enough money and probably a horse to pass through the continent and settle down in New York.

Hakan's facing frenzied efforts of James Bernan to extract gold in his own called "mine" is probably one of the earliest scenes of domination of mineral resources by the human in this novel. Greedy James finally unearthed pieces of gold, alone by his pickle and hammer, creeping from dawn until late the night in his holes. His dirty gold mining seeks to devastate lands, taint the lake's water, and add to the devastation of the lively ecosystem. However, he was too obsessed with mining gold that "Their living conditions deteriorated rapidly" as a result of his aim to take advantage of nature and make his fortune. Eileen Bernan, James' wife, and the children wearing torn and ragged outfits; Governed by the tatters, their flame-colored skin bubbled with blains. They even revealed white slough on their lips, noses, and earlobes. It did not take long that not only their clothes, but their very skin ripped to shred, and it hung off their body like a worn bandage. James' thirst after abusing rich mineral resources led to the loss of biodiversity, and toxic leavings had deleterious effects on his health and the people living around his mines.

Initially, the interruption of the icy lands in the unknown landscapes by a "White man," elaborates on the disturbance of the environment. With this in mind, we would face the association of aboriginal citizens of America with the natural environment, which is betokened as the pure soul of nature and ransacked by invaders. Local inhabitants were under constant attacks of white travelers with rotten skins and filthy outfits. However, unlike the colonizers, Indians were exceptionally clean and organized, and their faces displayed no tussle with the environmental milieu. Hakan understood that he had always assumed these far-flung provinces were vacant and that he had concluded they resided just during a short period while migrants were crossing through them. He further learned that everyone, himself involved, were trespassers, and this fact would reflect how the landscape was interrupted by colonizers. Indians were dominated by devices of white colonial authority, and their relation to white immigrants aroused the opposition to an everaugmenting sovereign control that demanded everlasting residence of the land. One afternoon, Hakan and Lorimer, found wounded Indians with their tents and shelters in smoke; "Fractured skulls, splintered bones, chests and limbs crushed by gunshots, entrails barely held in place by shaking hands" were products of armed aggressor's attacks to citizens. Lorimer, who was a naturalist, gained his intelligence by studying nature and animals, saved Hakan's life earlier by using his pure knowledge. He then had a struggle with assailants and eventually sent them off to remedy disabled people, in that he was a wise and humble man and did not consider himself superior to other beings. That moment Hakan though that the naturalist's face seeks to become like one of the locals and reveals no conflict either with nature or its offspring.

Among those who recovered swiftly, an old short-haired man had efficient treatments and was an expert physician with a sensitive understanding of the human body. In addition to his medical skills, his surgeries would have been done under two conditions: boiling the instruments and washing the hands. The lower rate of infections as the result of this practice bedazzled Lorimer; therefore, he concluded that the old man's wisdom represents the original American's attachment to the ecology of the land:

"Our learned scholars in our marbled
academies have failed to understand
what this wise man has gathered from his
observation of nature-that the
putrefaction that flowers in a wound and
the diseases that bloom in an open injury
can be nipped in the bud. The very seed of
these maladies can be boiled and wiped
away before it takes root in the flesh."
(Diaz, 2017, p. 97)

The scenery that had resembled so featureless to Hakan was soon an expanding puzzle he was keen to solve. However, there was limited time left after managing the business of staying alive. After all, it was apparent to everyone that one-third of injured people would die. The man 
with short hairs unclothed the corpse, and au naturel dead body went on a stretcher. Lorimer and Hakan made sure victims could be abandoned unsupervised for a few minutes, arranged to attend the stretcher-bearers. The sun was setting when stretcher bearers stopped and rolled up the stretcher, without any hesitation or special ceremony, in a random spot in the middle of the wilderness, and walked back to their campsite. Hakan had never seen anything like this, they abandoned the naked corpse, like it truly is, to transform it into part of nature, where the human truly belongs. It seems that Lorimer describes the exact roots of humankind, and its relation to other living forms on behalf of Diaz throughout the novel:

"What greater tribute than to be feasted upon by one's fellow creatures? What monument could be nobler than the breathing tomb of a coyote or the soaring urn of a vulture? What preservation more dependable? What resurrection more literal? This is true religion-knowing there is a bond among all living things. Having understood this, there is nothing to mourn, because even though nothing can ever be retained, nothing is ever lost. Can you imagine?" Lorimer asked again. "The relief. The freedom." (Diaz, 2017, p. 102).

Hakan's Journey so far pictures the world as "us all one" since both Lorimer and anonymous Native American man educated him with posthumanist views; that man can no longer consider his milieu only as a cover disperse exotic things and creatures associated with him just by their advantage. They taught Hakan caution, obligation, and the existence of an extreme bond among all living forms. The living way of Native Americans, their inspiring notions, and their immediate relationship to the environment shrewdly fortify the conspicuous green voice in Diaz's fiction that permeates through great parts of Posthumanism. However, nature is on the edge of disintegration since modern humankind seeks mastery over it with his mechanical instruments. It will be noticed that guns and human's new practices caused the extension of indigenous Americans, which were spirits of the planet, and led to the environmental changes as well as the deprivation of man. The day that Hakan faced a stone craved chair in the open wilderness, he asked himself if the seat is a sign. He gazed into it, "What does chair mean?" he came closer and touched it. Then he sat on the chair and suddenly felt infirm and fragile. At the same time, he reckons smaller and lonelier "There was something thrilling and comical about this." (Diaz, 2017) Was this chair a proof of human presides over the natural environment? Maybe it was a rapturous kingdom chair constructed by the human in the wild nature, even though by sitting on it, you would feel less significant than ever.

Hakan's sense of fellowship among nature and his wise tutors, however, appears as oppositional to his adventures in the city of Clangston with the autocratic, colonist woman, who killed Bernans for gold, and subsequently, the trespassers' trail with Jarvis, where the natural environment and its residents were a store to be manipulated. Hakan confronts the ruthless exploitation of the natural landscape and the severe colonization of both place and humankind beneath the shelter of opportunity and modernity. Later on, he gets stalk in the violence of coloniality and acts against his moral values, for he takes lives in Jarvis' trails, which parenthetically, only causes "feeling of sorrow and senselessness" for him. Had learned painful lessons walking around the continent, Hakan "arrived nowhere." He could neither fulfill his dreams nor find his brother, and it was time for turning back home.

He planned to travel back and discover James Brennan's buried gold. To do so, he must find Clangston, from where he could directly arrive to the mine and then Brennan's hidden cave. Having gold, he could discover a pathway into San Francisco and later, take a ship and sail away. His Journey to Clangston was like his many other journeys. However, Hakan got surprised how everything was changed in Clangston. Natural face of the city had been vanished and was replaced by lines of civilization; a night less wired mining town with aggressive individuals, fancy dressers, overloaded wagons, poor beggars, working children under the filth, and "black, brown, and red slime that covered the street from threshold to threshold like a stagnant river of 
mud, excrement, and rotting food." At the moment, Hakan notices a confident man marketing his fake tonics at the corner of the street with a crowd around him:

"Ladies and gentlemen, ladies and gentlemen!" he cried. "A physic for every condition, a tonic for each malady. ... And I have all the remedies right here. Blisters, blemishes, blackheads? ... You will never believe what marvels two or three drops of this powerful patent preparation here can work. Instant relief! Weak, weary, wan? You can't go on. You've had enough. Waking up is a struggle. ... Here is the cure. In this bottle. The rejuvenator! The one, the only, the original rejuvenator. A cordial made of herbs gathered by an Indian doctor, combined with the latest discoveries made by European chemical practitioners." (Diaz, 2017, p. 247).

He was the third scientist Hakan had faced in his thus far global journey. By Lorimer, the fact was an instant, innocent sense of touch. Reason grew later and verified it, yet initially, it had been a nearly tangible experience from the fountain of nature, similar to awakening from a lucid illusion. His other contact with science had been by the Native Indian man. Repeatedly, the proof of that man's genius left no room for ambiguity. His perception of the mortal anatomy and the best way to remedy it, his safe medicines and ointments, and his nearly exact methods of preventing infections were pieces of evidence from his authorization by the power of nature. However, this guy, with his tonics and medicines, was a clown and a deceiver and had nothing in common with his two masters. In the modern Clangston, everything was unreliable and immoral as if modernity turned people's lives upside down, and nobody cared about what was happening. Humankind now had dominated nature, seeing that Diaz inscribes, "Nothing left behind in the wilderness could ever be retrieved."

Hakan's way took him back to the spot he first started his journey. However, the landscape was like nothing Hakan had seen before; "Every plant had been forced into some artificial shape" in an oppressive method; every animal had been domesticated; water had been contained and redirected, and all around, "Indians in white made sure that each blade of grass stayed in place." Native Americans, the pure souls of the planet whom they had a deep-rooted relationship with the environment, just like any other element of nature, now working as slaves under modern white men dominance. One of these men was a wealthy Finnish man named Captain Altenbaum. Captain was an animal fur trader who was celebrating his triumph over natural environment and animals in his castle, and recently his ships were sailing through new territory of "Alaska" to get ice from here and there. The captain showed Hakan a globe and pointed out to Alaska: "Just the place for you...Whichever spot you choose, you can be sure that you will be left alone. And that game will be abundant" (Diaz, 2017), P. 265).

Hakan, however, inescapably, was part of this dirty game until the last moments. Captain Altenbaum's shipping company was continually disrupting Alaska's new lands, just like the formerly discovered America. Not only his fur trading industry is undoubtedly a hassle for local ecosystems, but the new notion of the ice industry adds to global warming and the extinction of several species. Humankind had de-world the world and brought nothing but wreck and bafflement for himself. In the distance's white old man ends up where the narrative begins, in a horizonless white plain, breaking the stillness of nature. The constant interruption that eventually resulted in frustration of Hakan's ambitions and made him an unfortunate man.

Inspired by posthumanism, the novel illustrates how the underpinnings of the posthumanistic constellation of thought could be encoded in literary work. For instance, Diaz implies the crisis of no longer standing with nature, and mankind privileging of the environment, which both are the chief exemplars of the posthumanism perspective. According to him, excavating gold had intensified "the void" between the human and ecology, and "separated" Bernans from the natural sphere, as if they are standing above or outside it. In other scenes throughout the novel, Lorimer probably speaks for Diaz in the shed of posthumanism since he often claims "knowing nature means learning how to be" as humankind in correlation with his only actual 
domicile, planet earth. As stands in what Diaz argues, the whole life is "connected," and all living beings are "tied" together in this "natural kingdom" which provides a network among all beings; Therefore, we are "us all one" and to trace the roots we need to monitor the consistent discourse of creatures. Hereby, Lorimer describes the exact roots of mankind and the mentality of a "bond" among all living forms (including humankind) on behalf of Diaz. Thus, the narrative depicts how Hakan felt the delight of being "a living thing among living things" shortly afterward. He could now comprehend that the land, which had sheltered him for decades, is "part of his body," and therefore, nature or its offspring had no intention to "kill or amaze" him. In the end, the narrator uses the word "punitive" and "angry" for describing the artificial design of the modern city and expresses how the new world is turning to be "complex" and "frightening" as the human race seeking power over it.

This novel should give us cause to worry. Hernan Diaz seems to bear a posthumanist mentality while writing In the Distance novel, and if not, he evidently had a vivid record of this notion in his mind. The narrative inscribes sequences of pattern like events by exercising posthuman style of writing which ultimately lead to the triumph of the human over nature and decay of the environment; an ending which eventually heads to the terrifying doom of human civilization, including Hakan. In the distance's protagonist, Hakan, involuntarily was a part of the systematic exploitation of nature by colonizers, and became alienated and manipulated through his traumatic journey. However, his interactions-with Indians, nature, animals, minerals, and ecowarrior scientists-brought him a universal sensibility and reminded him of his inextricably bound up relation with other beings, apart from their outside form. Images of human domination of nature in this novel are admittedly an earthly variant of the apocalypse. What makes it even more horrifying is the infinite avarice of humankind as a slip that derails the human-non-human network; the continuation of such abusing points to the destruction of the whole environment, which all in all, do not hold out any hope that things would change for good. At least not for years afterward.

\section{Conclusion}

The study explored the posthumanism mindset reflected in one of the contemporary novels In the Distance by Hernan Diaz, and questioned the taxonomy of the human and the non-human by breaking the anthropocentrism and de-centering the human race from its dedicated position of exceptionalism. The novel is best understood as an endeavor to awaken us to the perils for the environment by making a journey toward consciousness. In doing so, an attempt was made to uncover the fiction's underlying assumptions as to how humanity is shifting the boundaries among living forms and exploiting the non-human sphere since the modern period at the turn of the 20th century. To put it another way, the fiction doubts the widely acknowledged notion of anthropocentrism and describes the misuse of mineral, vegetal, and animal forms by the modern human. The narrative is about to give voice to abused living beings by employing a posthuman way of thinking; therefore, Hernan Diaz can be considered as one of the contemporary driving forces of posthumanism reflecting upon the relation of humankind and nature in his fiction. He interestingly points out how furtherance of the human race has made us a threat for planet earth and continuously makes an attempt to warn us against consequences of the environmental destruction, the unthoughtful objectification that not only had resulted in the destruction of the human-non-human network but also led to extreme incompleteness and misery of man. Diaz vividly illustrates how the pattern of the landscape had changed due to humanity's modern activities in a short period. He, therefore, depicts modern American civilization in the early 20th century and mentions that even large settlements rising from the ashes of the destructed environment to improve mankind's living conditions can lead to the collapse of moral ethics in human's society.

The brief epilogue to an analytical reading of In the Distance fiction would inform us about where the world was, where it is in the status quo, and which rout it is taking in the near future. The fictional world of Hernan Diaz, makes us rethink human singularity and warns us about the adverse repercussions of the man 
seeking authority over nature, promoting an eco-morally mindset: we might guarantee the presence of life on our planet, unless, of course, we are happy with the way things are!

\section{References}

Ağın, B. (2016). The Ecological Posthuman in Lee's Tarboy and Tan and Ruhemann's The Lost Thing. CLCWeb: Comparative Literature and Culture, 18(3), 3.

Aretoulakis, E. (2014). Towards a Posthumanist Ecology: Nature without Humanity in Wordsworth and Shelley. European Journal of English Studies, 18(2), 172-190.

Badmington, N. (2003). Theorizing posthumanism. Cultural Critique, (53), 10-27.

Bandyopadhyay, D. (2011). An Ecocritical Commentary on the Posthuman Condition in Margaret Atwood's Fiction. The Criterion: An International Journal in English, 1(1), 1-14.

Bolter, J. D. (2016). Posthumanism. The international encyclopedia of communication theory and philosophy, 1-8.

Childs, P., \& Williams, P. (2014). An introduction to post-colonial theory: London: Routledge.

Diaz, H. (2017). In the Distance: Minnesota: Coffee House Press.

Gerhardt, C. (2006). "Syllabled to us for names": Native American echoes in Walt Whitman's green poetics. Nature in Literary and Cultural Studies: Transatlantic Conversations on Ecocriticism, 3, 209.

Gonçalves, D. (2017). "SANDCASTLES IN THE WIND”: DYSTOPIA, ECOCRITICISM,
AND THE POSTHUMAN BODY IN ORYX \& CRAKE (ATWOOD, 2003). Sociopoética, 1(17).

Hassan, I. (1977). Prometheus as performer: Toward a posthumanist culture? The Georgia Review, 31(4), 830-850.

Huggan, G. (2004). " Greening" Postcolonialism: Ecocritical Perspectives. MFS Modern Fiction Studies, 50(3), 701-733.

Iovino, S. (2016). Posthumanism in literature and ecocriticism. Rel.: Beyond Anthropocentrism, 4, 11.

Jendrysik, M. S. (2011). Back to the garden: New visions of posthuman futures. Utopian Studies, 22(1), 34-51.

LeMenager, S., Shewry, T., \& Hiltner, K. (2011). Environmental criticism for the twenty-first century (Vol. 1): London \& New York: Routledge. 